EUROPEAN CENTRAL BANK

WORKING PAPER SERIES

N0. 350 / APRIL 2004

\title{
EXCHANGE-RATE POLICY AND THE \\ ZERO BOUND ON NOMINAL INTEREST RATES
}

by Günter Coenen and Volker Wieland
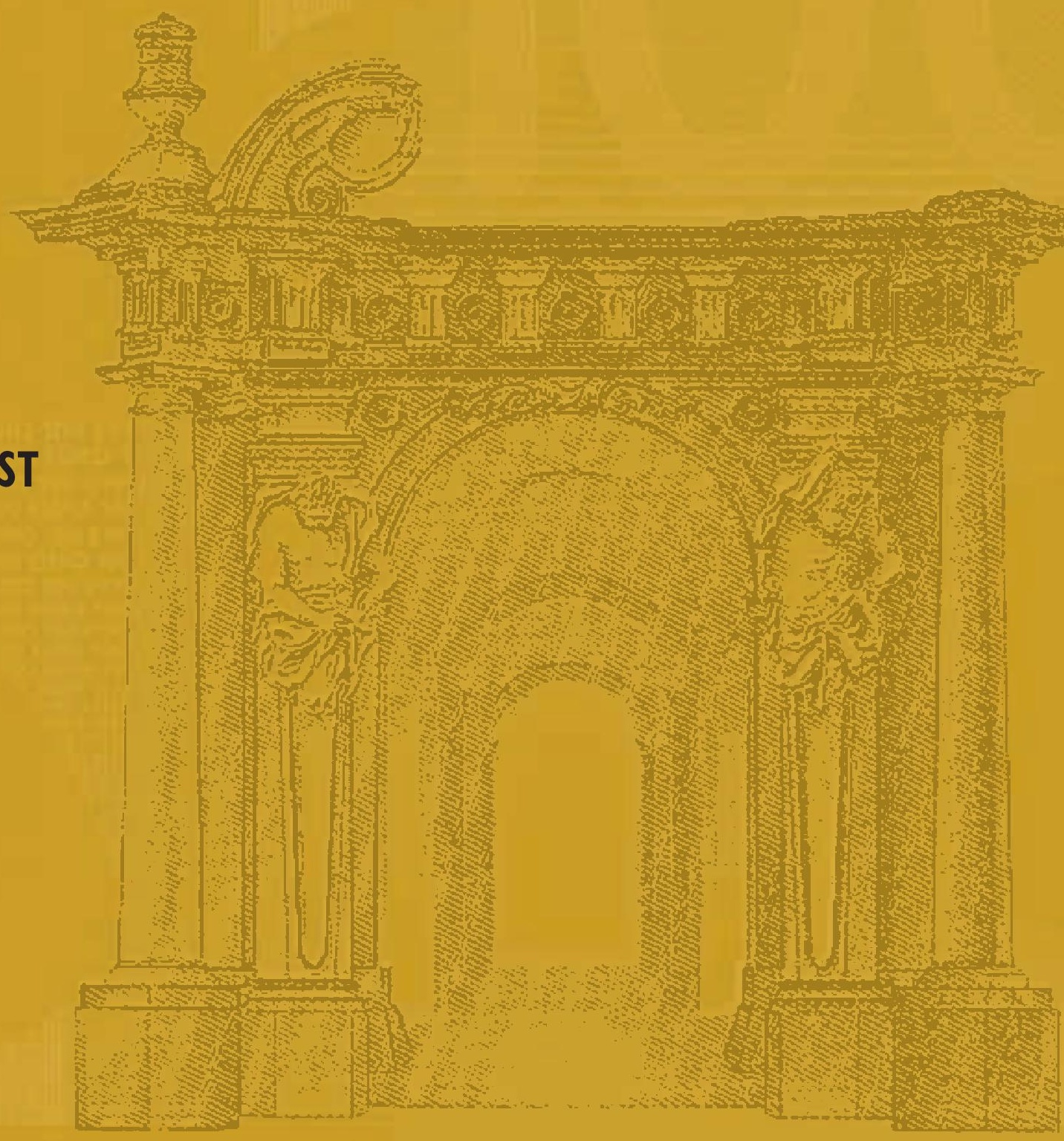
EXCHANGE-RATE POLICY AND THE ZERO BOUND ON NOMINAL INTEREST RATES'

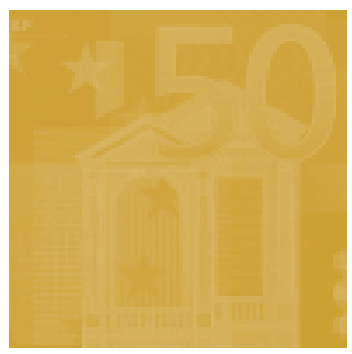

\author{
by Günter Coenen ${ }^{2}$ \\ and Volker Wieland ${ }^{3}$
}

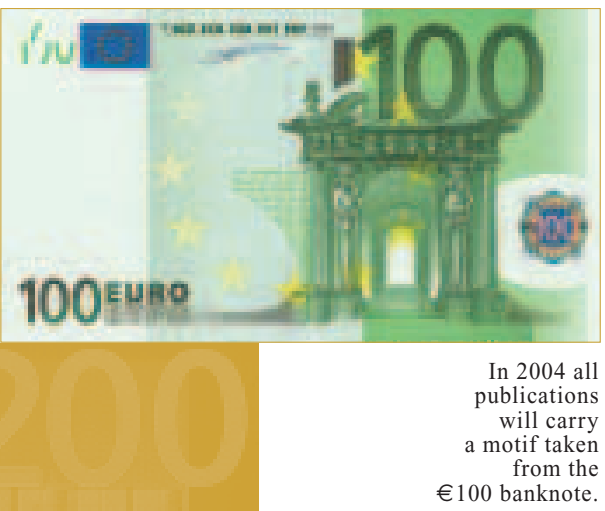

This paper can be downloaded without charge from http://www.ecb.int or from the Social Science Research Network electronic library at http://ssrn.com/abstract_id $=533012$.

I This paper was prepared for the Annual Meeting of the American Econonomic Association in San Diego, January 2004. We are grateful for helpful comments by Gianluca Benigno, Chris Gust, Martin Uribe and Bob Tetlow. The opinions expressed are those of the authors and do not necessarily reflect views of the European Central Bank. Volker Wieland served as a consultant in the Directorate General Research at

the European Central Bank while preparing this paper. Any errors are of course the sole responsibility of the authors.

2 Directorate General Research, European Central Bank, Kaiserstrasse 29, D-603 I I Frankfurt am Main, Germany, phone: 4969 1344-7887, e-mail: gunter.coenen@ecb.int, homepage: http://www.guentercoenen.com 


\section{드 European Central Bank, 2004}

\section{Address}

Kaiserstrasse 29

60311 Frankfurt am Main, Germany

Postal address

Postfach 160319

60066 Frankfurt am Main, Germany

Telephone

+496913440

\section{Internet}

http://www.ecb.int

Fax

+496913446000

Telex

411144 ecb d

All rights reserved.

Reproduction for educational and noncommercial purposes is permitted provided that the source is acknowledged.

The views expressed in this paper do not necessarily reflect those of the European Central Bank.

The statement of purpose for the ECB Working Paper Series is available from the ECB website, http://www.ecb.int.

ISSN 1561-0810 (print)

ISSN 1725-2806 (online) 


\section{CONTENTS}

Abstract 4

Non-technical summary 5

I. Introduction 6

II. Recession, deflation and the zero-interest-rate bound

III. Exchange-rate peg versus price-level targeting || 0

IV. Implications of imperfect credibility || 3

V. Conclusions ||

References I5

European Central Bank working paper series I 6 


\begin{abstract}
In this paper, we study the effectiveness of monetary policy in a severe recession and deflation when nominal interest rates are bounded at zero. We compare two alternative proposals for ameliorating the effect of the zero bound: an exchange-rate peg and price-level targeting. We conduct this quantitative comparison in an empirical macroeconometric model of Japan, the United States and the euro area. Furthermore, we use a stylized micro-founded two-country model to check our qualitative findings. We find that both proposals succeed in generating inflationary expectations and work almost equally well under full credibility of monetary policy. However, price-level targeting may be less effective under imperfect credibility, because the announced price-level target path is not directly observable.
\end{abstract}

JEL Classification System: E31, E52, E58, E61

Keywords: monetary policy rules, zero-interest-rate bound, liquidity trap, nominal rigidities, exchange rates. 


\section{Non-technical summary}

Researchers, practitioners and policymakers alike have made proposals for avoiding and if necessary escaping deflation. In this paper, we focus on two proposals that have dominated the debate most recently: an exchange-rate peg and price-level targeting. Svensson (2001, 2003), in particular, has emphasized that the central bank may create expectations of inflation by devaluing and pegging the exchange rate for some time. Alternatively, the central bank can try to manage expectations regarding future interest-rate policy by announcing a target path for the price level and thus induce inflationary expectations. The latter proposal has been pushed most recently by Eggertsson and Woodford (2003).

Our objective is to compare the effectiveness of an exchange-rate peg and price-level targeting in stimulating the Japanese economy in a severe recession and deflation scenario when nominal interest rates are bounded at zero. We conduct a quantitative evaluation in the estimated macroeconomic model with rational expectations and nominal rigidities of Coenen and Wieland (2002) that covers the three largest economies, the United States, the euro area and Japan. We recognize the zero-interest-rate bound explicitly in the analysis and use numerical methods for solving nonlinear rational expectations models. Since this model is not fully developed from microeconomic foundations we also cross-check our findings using a stylized two-country model with imperfect competition that is derived from optimizing behavior of households and firms given Calvo-type price contracts. This model is taken from Benigno and Benigno (2001). The qualitative findings regarding the impact of the zero bound and the two alternative proposals are quite similar in the two models. Not surprisingly, the dynamics observed in the optimizing model are highly stylized and lack the persistence observed in the data, but they provide some additional support for our conclusions from a theoretical perspective.

Our quantitative findings in the estimated three-country model indicate an economically significant impact of the zero bound. Furthermore, we show that exchange-rate-based and price-level-target-based proposals are equally effective in inducing inflationary expectations and stimulating the economy. This result depends on the assumptions of rational expectations and full credibility of monetary policy. Price-level targeting may be less effective under imperfect credibility, because the announced price-level target path is not directly observable. In particular, we show that if a significant percentage of market participants doubts that the central bank has truly adopted a price-level target, the central bank's announcement is not anymore as effective in mitigating the impact of the zero bound. The exchange-rate peg at least offers the advantage that the public can observe every period whether the central bank maintains the exchange-rate peg. 


\section{Introduction}

Due to the recent experience in Japan the threat of deflation and a liquidity trap has taken center stage in the debate on the proper formulation of monetary policy. Deflationary episodes present a particular problem for monetary policy because the effectiveness of its main instrument, the short-term nominal interest rate, may be limited by the zero lower bound. ${ }^{1}$ With interest rates near zero, the central bank will not be able to offset recessionary shocks by lowering nominal and thereby real interest rates. Furthermore, deflationary shocks may raise real interest rates and worsen such a recession.

Researchers, practitioners and policymakers alike have made proposals for avoiding and if necessary escaping deflation. In this paper, we focus on two proposals that have dominated the debate most recently: an exchange-rate peg and price-level targeting. Svensson (2001, 2003), in particular, has emphasized that the central bank may create expectations of inflation by devaluing and pegging the exchange rate for some time. ${ }^{2}$ Alternatively, the central bank can try to manage expectations regarding future interest-rate policy by announcing a target path for the price level and thus induce inflationary expectations. The latter proposal has been pushed most recently by Eggertson and Woodford (2003).

Our objective is to compare the effectiveness of an exchange-rate-peg and price-level targeting in stimulating the Japanese economy in a severe recession and deflation scenario when nominal interest rates are bounded at zero. We conduct a quantitative evaluation in the estimated macroeconomic model of Coenen and Wieland (2002) that comprises the United States, the euro area and Japan. We recognize the zero-interest-rate bound explicitly in the analysis and use numerical methods for solving nonlinear rational expectations

\footnotetext{
${ }^{1}$ Nominal interest rates on deposits cannot fall substantially below zero, as long as interest-free currency constitutes an alternative store of value (McCallum, 2000).

${ }^{2}$ Related proposals for depreciating the exchange rate have been made by Orphanides and Wieland (2000) and McCallum (2002) and have been compared with Svensson's proposal by Coenen and Wieland (2003).
} 
models. Since this model is not fully developed from microeconomic foundations we check whether similar results obtain in the stylized two-country model of Benigno and Benigno (2001) that is derived under optimizing behavior of households and firms with imperfect competition and Calvo-type price contracts.

\section{Recession, Deflation and the Zero-Interest-Rate Bound}

In the model of Coenen and Wieland (2002) monetary policy is neutral in the long-run, because expectations in financial markets, goods markets and labor markets are formed in a rational, model-consistent manner. However, short-run real effects arise due to the presence of nominal rigidities in the form of staggered contracts. Model parameters are estimated using quarterly data from 1974 to 1999 and the model fits empirical inflation and output dynamics in the United States, the euro area and Japan surprisingly well.

As a benchmark we assume that monetary policy follows Taylor's rule. Thus, the nominal short-term interest rate, $i_{t}$, responds to deviations of the annual inflation rate, $\pi_{t}$, from the target, $\pi^{*}$, and deviations of output from potential, $q_{t}$, as follows:

$$
i_{t}=r^{*}+\pi_{t}+0.5\left(\pi_{t}-\pi^{*}\right)+0.5 q_{t},
$$

where $r^{*}$ refers to the equilibrium real interest rate. Under normal circumstances, when the short-term nominal interest rate is well above zero, the central bank may ease monetary policy by expanding the supply of the monetary base and bringing down the short-term rate of interest. Since prices of goods and services adjust more slowly than those on financial instruments, such a money injection reduces real interest rates and provides a stimulus to the economy. Whenever monetary policy is expressed in form of an interest rate rule, it is implicitly assumed that the central bank injects liquidity so as to achieve the rate that is prescribed by the interest rate rule. However, at the zero bound further injections of 
liquidity have no additional effect on the nominal interest rate, and a negative interest rate prescribed by the interest rate rule cannot be implemented.

To illustrate the potentially dramatic consequences of the zero-interest-rate bound and deflation we simulate an extended period of recessionary and deflationary shocks in the Japan block of our three-country model. Initial conditions are set to steady state with an inflation target of $1 \%$, a real equilibrium rate of $1.5 \%$, and thus an equilibrium nominal interest rate of $2.5 \%$. Then, the economy is hit by a sequence of negative demand and contract price shocks for a total period of 5 years. The magnitude of the demand and contract price shocks is set equal to -1.5 and -1 percentage points respectively.

The output and inflation performance of the Japanese economy if monetary policy were to stick to Taylor's rule is shown by the solid lines in Figure 1. The left panel reports the output gap while the right panel displays the annual rate of inflation. As a result of the sequence of shocks the Japanese economy plunges into a double-digit recession (with an output gap of up to -14\%) while experiencing a massive decline in the price level (with a rate of inflation close to $-11 \%)$.
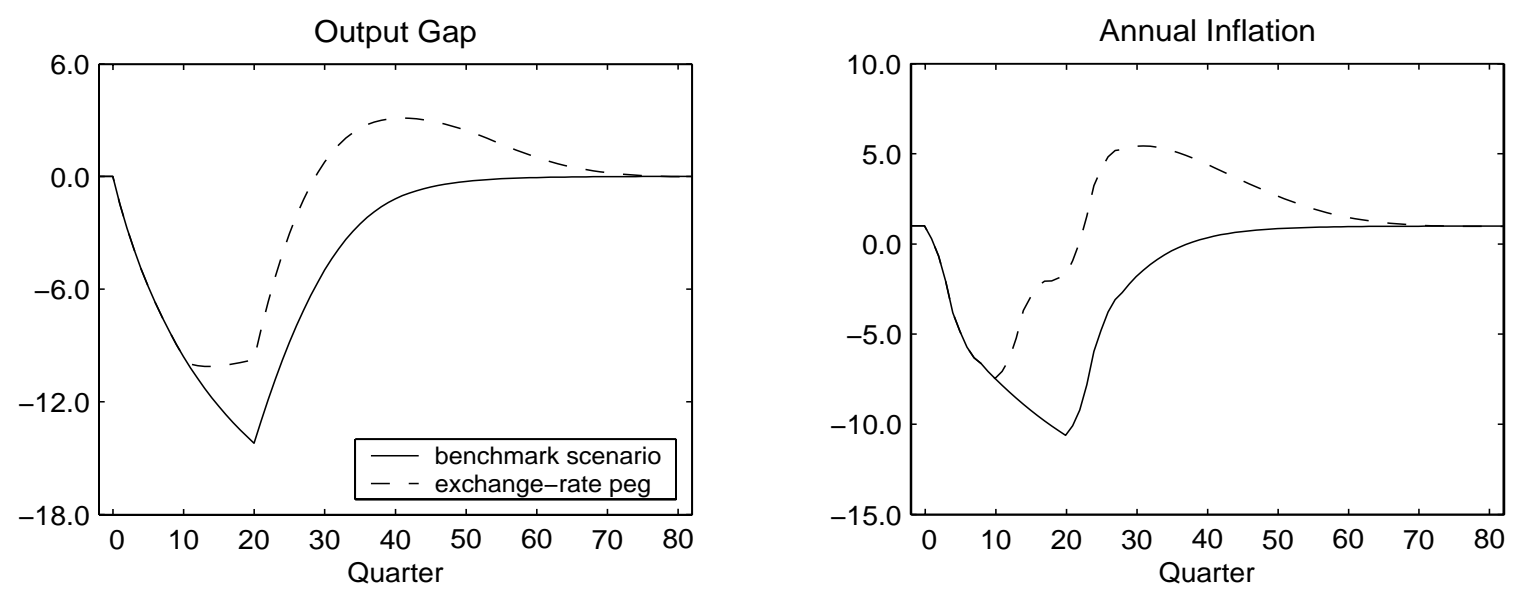

Figure 1. Output Gap and Inflation in a Severe Recession and Deflation 
To a large extent the depth of this recession is due to the reduced effectiveness of monetary policy in a liquidity trap. As shown by the solid line in the left panel of Figure 2 nominal interest rates are constrained at zero for almost a decade. Thus, deflation leads to an increase in the long-term real interest rate up to $3 \%$ and the Yen temporarily appreciates in real terms. Consequently, the recession and deflation are much more pronounced than they would be in the absence of the zero bound.
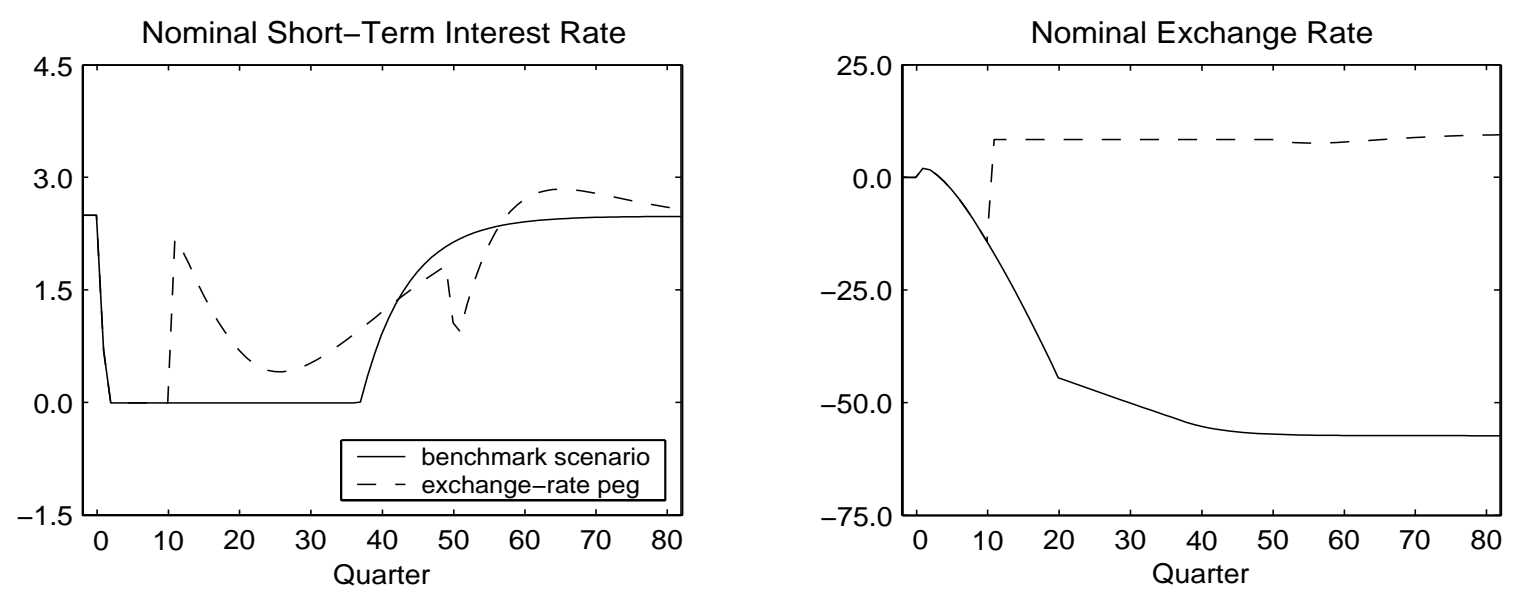

Figure 2. Interest Rate and Exchange Rate in a Severe Recession and

\section{DEFLATion}

A counterfactual simulation (not shown in this figure), in which the zero bound is not imposed, indicates that the central bank would like to respond to the onset of recession and disinflation by drastically lowering nominal interest rates. If this were possible the long-term real interest rate would decline by about $4 \%$ and the central bank would be able to contain the output gap and deflation around $-9 \%$ and $-7 \%$ respectively. The reduction in nominal interest rates would be accompanied by an $11 \%$ real depreciation in trade-weighted terms. 


\section{Exchange-Rate Peg versus Price-Level Targeting}

Svensson (2001) offers what he calls a foolproof way of escaping from a liquidity trap. With interest rates constrained at zero and ongoing deflation he recommends that the central bank stimulates the economy and raises inflationary expectations by switching to an exchangerate peg at a substantially devalued exchange rate. The exchange-rate peg is intended to be temporary and should be abandoned in favor of price-level or inflation targeting once the price-level reaches a pre-announced target path. His concrete proposal is as follows:

- Announce a devaluation and subsequent peg of the nominal exchange rate at a given target,

$$
s_{t}=\bar{s}, \quad t \geq t_{0}
$$

- announce that the peg will be abandoned once the price level again coincides with an upward-sloping target path,

$$
p_{t}^{*}=p_{t_{0}}^{*}+0.25 \pi^{*}\left(t-t_{0}\right), \quad t \geq t_{0}
$$

with $p_{t_{0}}^{*}>p_{t_{0}}$ and $\pi^{*}>0$. From then on, a policy of price-level or inflation targeting may be followed. ${ }^{3}$

Svensson emphasizes that the central bank should be able to enforce the peg at a devalued rate by standing ready to buy up foreign currency at this rate to an unlimited extent if necessary. This situation differs from the defense of an overvalued exchange rate, which requires selling foreign currency and poses the risk of running out of foreign exchange reserves.

\footnotetext{
${ }^{3}$ If the target inflation that is implicit in the price-level target path differs from the foreign target inflation rate then a crawling exchange-rate peg may be more appropriate than a fixed peg.
} 
We investigate the consequences of Svensson's proposal if it is adopted after the central bank has observed 9 quarters of zero nominal interest rates. The outcome is shown by the dashed lines in Figure 1 and Figure 2. In our simulation the peg is implemented with respect to the U.S. Dollar and $s_{t}$ denotes the bilateral nominal Yen/U.S. Dollar exchange rate. Important choice variables in Svensson's proposal are the initial price level of the implied target path, the extent of the devaluation and the length of the peg.

The exchange-rate peg delivers the intended results. As shown in Figure 1 (dashed line) inflationary expectations are jump-started and rise very quickly. As a result, the real interest rate declines very rapidly, the real exchange rate depreciates, and the economy recovers more quickly from the recession. The implied nominal devaluation is shown in the right panel of Figure $\mathbf{2}$ (dashed line). It induces a $15 \%$ real depreciation in the tradeweighted exchange rate.

Uncovered interest parity and exchange-rate expectations play a key role. Once the central bank announces the peg the expected exchange-rate change is zero and the nominal interest rate rises to the level of the foreign rate absent any risk premium. The left panel of Figure 2 (dashed line) confirms that the nominal interest rate jumps to a positive level immediately upon the start of the peg.

The preceding analysis of Svensson's proposed exchange-rate peg emphasizes that escaping from the liquidity trap requires generating expectations of inflation. However, the exchange-rate peg is not a necessary ingredient. Inflationary expectations may simply be achieved by promising future policy easing. Using a small micro-founded closed-economy model Eggertson and Woodford (2003) show that it is optimal for the central bank to commit to keeping nominal interest rates lower in the future in order to affect expectations of inflation while the zero bound is still binding. They also show that the optimal policy 
can be implemented through commitment to a history-dependent rule using a price-level target that evolves over time. Furthermore, they find that a simpler rule with a fixed target achieves most of the benefits of the optimal policy. Inspired by their findings we investigate whether switching to a price-level target alone would be sufficient to stimulate inflationary expectations in our estimated model. More precisely, we consider the performance of the following policy proposal:

- Announce an upward-sloping price-level target path as defined by equation (3) and replace the inflation target in Taylor's rule (equation (1)) with this price-level target, thereby committing to lower interest rates in the future until the price gap is completely closed.

Figure 3 compares the performance of the Japanese economy in our model when the central bank switches to the price-level target (dashed-dotted line) after 9 quarters of zero interest rates with the performance under a switch to an exchange-rate peg (dashed line).
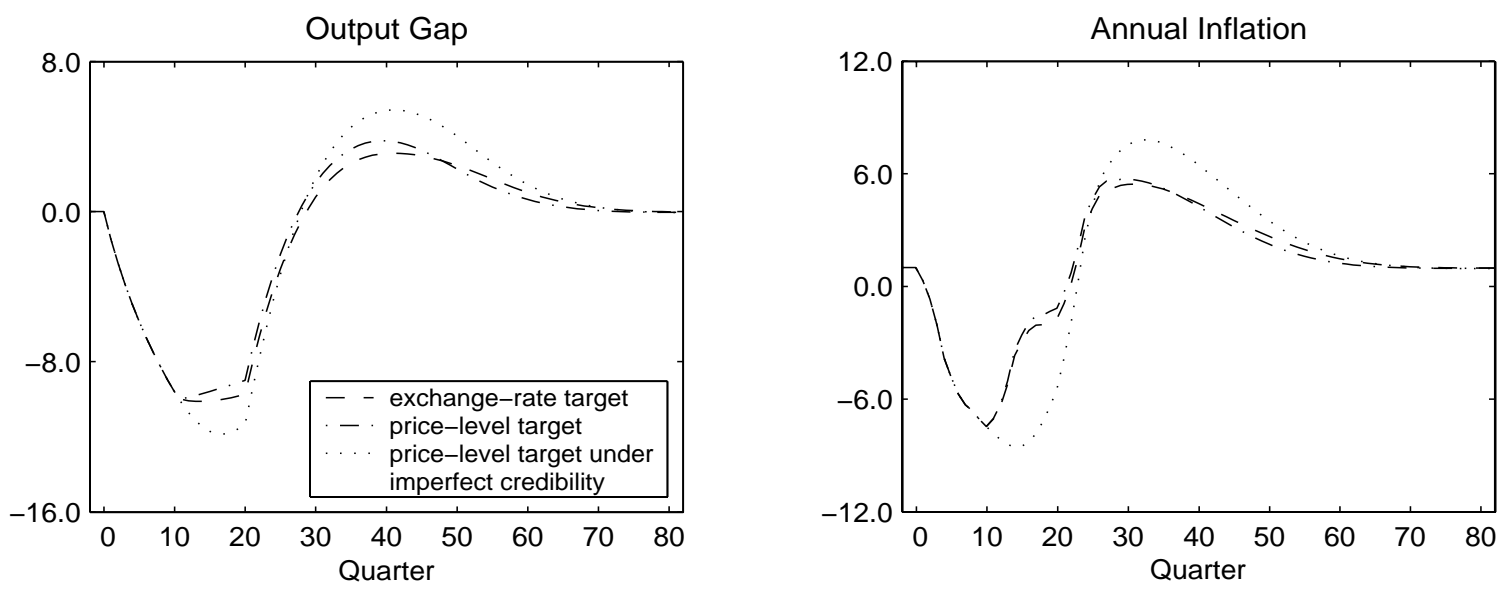

Figure 3. Exchange-Rate Peg versus Price-Level Targeting 
Surprisingly, switching to the price-level target alone is just as effective in generating inflationary expectations as the exchange-rate peg. Output and inflation return even a bit more quickly to steady-state, the reason being that the nominal interest rate remains at zero much longer and that consequently the long-term real rate falls lower and the real depreciation is a bit larger than under the exchange-rate peg.

\section{Implications of Imperfect Credibility}

So far, exchange-rate-based and price-level-target-based approaches appear equally effective in inducing inflationary expectations in a liquidity trap. From a practical perspective, however, there is an important difference. While the exchange-rate peg can be verified every day it is maintained by the central bank, the price-level target path and resulting price gap are not directly observable. Thus, the success of price-level targeting may depend very much on the credibility of the announced target path.

To gauge the validity of our findings we consider an alternative scenario, in which a share $\lambda$ of market participants trust the central bank's commitment to the price-level target $(0 \leq \lambda \leq 1)$ while the others remain sceptical regarding the policy switch $(1-\lambda)$. Sceptical market participants still believe that the central bank will pursue an inflation target rather than a price-level target. In other words, they do not believe that the central bank intends to induce sufficient inflation in the future to fully make up the price-level gap. We assume that the share $\lambda$ converges to one at an exponential rate and report output and inflation outcomes for an initial value of 0.2 in Figure 3 (dotted lines). We find that the benefits of a switch to price-level targeting are reduced substantially if a large share of market participants does not immediately buy the central bank's announcement. 


\section{Conclusions}

The strength of the estimated three-country model lies in its ability to match the observed degree of persistence of output and inflation in Japan, the United States and the euro area. However, the model differs from a standard New-Keynesian micro-founded model in several ways, most importantly because lags of the output gap are included in the behavioral demand equations. To investigate the validity of our results from a theoretical perspective we have simulated a similar recession and deflation scenario in the micro-founded twocountry model of Benigno and Benigno (2001). ${ }^{4}$ We have obtained qualitatively similar results as far as the effect of the zero bound on output, inflation and interest rates is concerned. However, not surprisingly, the effect of the zero bound is rather small and the dynamics are highly stylized due to the lack of intrinsic persistence in the micro-founded model.

Based on our quantitative findings in the estimated model we conclude that the zero bound on nominal interest rates has an economically significant impact on the macroeconomic performance of the Japanese economy in a recession and deflation scenario. We also find that the central bank may improve performance substantially by devaluing the exchange rate and switching to an exchange-rate peg or by committing to a price-level target path and an interest-rate rule that will close the price gap in the future. From a practical perspective, however, the lack of immediate verifiability may render a price-leveltargeting-based proposal for escaping from a liquidity trap less credible and consequently less effective.

\footnotetext{
${ }^{4}$ For a more detailed presentation of these results see Coenen and Wieland (2004).
} 


\section{REFERENCES}

Benigno, Gianluca and Benigno, Pierpaolo. "Monetary Policy Rules and the Exchange Rate." CEPR Discussion Paper No. 2807, May 2001.

Coenen, Günter and Wieland, Volker. "Inflation Dynamics and International Linkages: A Model of the United States, the Euro Area and Japan." ECB Working Paper No. 181, September 2002.

Coenen, Günter and Wieland, Volker. "The Zero-Interest-Rate Bound and the Role of the Exchange Rate for Monetary Policy in Japan." Journal of Monetary Economics, July 2003, 50(5), pp. 1071-1101.

Coenen, Günter and Wieland, Volker. "Exchange-Rate Policy and the Zero Bound on Nominal Interest Rates." Unpublished manuscript, European Central Bank, March 2004.

Eggertsson, Gauti and Woodford, Michael. "The Zero Bound on Interest Rates and Optimal Monetary Policy." Brookings Papers on Economic Activity, 1, 2003, pp. 139-233

McCallum, Bennett T.. "Theoretical Analysis Regarding a Zero Lower Bound on Nominal Interest Rates." Journal of Money, Credit and Banking, 2000, 32(4), pp. 870-904.

McCallum, Bennett T.. "Inflation Targeting and the Liquidity Trap," in Norman Loayza and Raimundo Soto, eds., Inflation Targeting: Design, Performance, Challenges, Central Bank of Chile, November 2002, pp. 395-437.

Orphanides, Athanasios and Wieland, Volker. "Efficient Monetary Policy Design near Price Stability." Journal of the Japanese and International Economies, December 2000, 14(4), pp. 327-65.

Svensson, Lars E.O.. "The Zero Bound in an Open Economy: A Foolproof Way of Escaping from a Liquidity Trap." Monetary and Economic Studies, February 2001, 19(1), pp. 277-312.

Svensson, Lars E.O.. "The Magic of the Exchange Rate: Optimal Escape from a Liquidity Trap in Small and Large Open Economies." Unpublished manuscript, Princeton University, December 2003. 


\section{European Central Bank working paper series}

For a complete list of Working Papers published by the ECB, please visit the ECB's website (http://www.ecb.int).

202 "Aggregate loans to the euro area private sector" by A. Calza, M. Manrique and J. Sousa, January 2003.

203 "Myopic loss aversion, disappointment aversion and the equity premium puzzle" by D. Fielding and L. Stracca, January 2003.

204 "Asymmetric dynamics in the correlations of global equity and bond returns" by L. Cappiello, R.F. Engle and K. Sheppard, January 2003.

205 "Real exchange rate in an inter-temporal n-country-model with incomplete markets" by B. Mercereau, January 2003.

206 "Empirical estimates of reaction functions for the euro area" by D. Gerdesmeier and B. Roffia, January 2003.

207 “A comprehensive model on the euro overnight rate” by F. R. Würtz, January 2003.

208 "Do demographic changes affect risk premiums? Evidence from international data" by A. Ang and A. Maddaloni, January 2003.

209 “A framework for collateral risk control determination” by D. Cossin, Z. Huang, D. Aunon-Nerin and F. González, January 2003.

210 "Anticipated Ramsey reforms and the uniform taxation principle: the role of international financial markets" by S. Schmitt-Grohé and M. Uribe, January 2003.

211 “Self-control and savings” by P. Michel and J.P. Vidal, January 2003.

212 "Modelling the implied probability of stock market movements" by E. Glatzer and M. Scheicher, January 2003.

213 “Aggregation and euro area Phillips curves” by S. Fabiani and J. Morgan, February 2003.

214 “On the selection of forecasting models” by A. Inoue and L. Kilian, February 2003.

215 "Budget institutions and fiscal performance in Central and Eastern European countries" by H. Gleich, February 2003.

216 "The admission of accession countries to an enlarged monetary union: a tentative assessment” by M. Ca'Zorzi and R. A. De Santis, February 2003.

217 "The role of product market regulations in the process of structural change" by J. Messina, March 2003. 
218 "The zero-interest-rate bound and the role of the exchange rate for monetary policy in Japan” by G. Coenen and V. Wieland, March 2003.

219 "Extra-euro area manufacturing import prices and exchange rate pass-through" by B. Anderton, March 2003.

220 "The allocation of competencies in an international union: a positive analysis" by M. Ruta, April 2003.

221 "Estimating risk premia in money market rates" by A. Durré, S. Evjen and R. Pilegaard, April 2003.

222 "Inflation dynamics and subjective expectations in the United States" by K. Adam and M. Padula, April 2003.

223 “Optimal monetary policy with imperfect common knowledge” by K. Adam, April 2003.

224 "The rise of the yen vis-à-vis the ("synthetic") euro: is it supported by economic fundamentals?” by C. Osbat, R. Rüffer and B. Schnatz, April 2003.

225 "Productivity and the ("synthetic") euro-dollar exchange rate" by C. Osbat, F. Vijselaar and B. Schnatz, April 2003.

226 "The central banker as a risk manager: quantifying and forecasting inflation risks" by L. Kilian and S. Manganelli, April 2003.

227 “Monetary policy in a low pass-through environment” by T. Monacelli, April 2003.

228 "Monetary policy shocks - a nonfundamental look at the data" by M. Klaeffing, May 2003.

229 “How does the ECB target inflation?” by P. Surico, May 2003.

230 "The euro area financial system: structure, integration and policy initiatives" by P. Hartmann, A. Maddaloni and S. Manganelli, May 2003.

23I "Price stability and monetary policy effectiveness when nominal interest rates are bounded at zero" by G. Coenen, A. Orphanides and V. Wieland, May 2003.

232 "Describing the Fed's conduct with Taylor rules: is interest rate smoothing important?" by E. Castelnuovo, May 2003.

233 "The natural real rate of interest in the euro area" by N. Giammarioli and N. Valla, May 2003.

234 "Unemployment, hysteresis and transition" by M. León-Ledesma and P. McAdam, May 2003.

235 "Volatility of interest rates in the euro area: evidence from high frequency data" by N. Cassola and C. Morana, June 2003. 
236 "Swiss monetary targeting 1974-1996: the role of internal policy analysis" by G. Rich, June 2003.

237 "Growth expectations, capital flows and international risk sharing" by O. Castrén, M. Miller and R. Stiegert, June 2003.

238 "The impact of monetary union on trade prices" by R. Anderton, R. E. Baldwin and D. Taglioni, June 2003.

239 "Temporary shocks and unavoidable transitions to a high-unemployment regime" by W. J. Denhaan, June 2003.

240 "Monetary policy transmission in the euro area: any changes after EMU?" by I. Angeloni and M. Ehrmann, July 2003.

24I Maintaining price stability under free-floating: a fearless way out of the corner?" by C. Detken and V. Gaspar, July 2003.

242 "Public sector efficiency: an international comparison" by A. Afonso, L. Schuknecht and V. Tanzi, July 2003.

243 "Pass-through of external shocks to euro area inflation" by E. Hahn, July 2003.

244 "How does the ECB allot liquidity in its weekly main refinancing operations? A look at the empirical evidence” by S. Ejerskov, C. Martin Moss and L. Stracca, July 2003.

245 "Money and payments: a modern perspective" by C. Holthausen and C. Monnet, July 2003.

246 "Public finances and long-term growth in Europe - evidence from a panel data analysis" by D. R. de Ávila Torrijos and R. Strauch, July 2003.

247 "Forecasting euro area inflation: does aggregating forecasts by HICP component improve forecast accuracy?" by K. Hubrich, August 2003.

248 “Exchange rates and fundamentals" by C. Engel and K. D. West, August 2003.

249 "Trade advantages and specialisation dynamics in acceding countries" by A. Zaghini, August 2003.

250 "Persistence, the transmission mechanism and robust monetary policy" by I. Angeloni, G. Coenen and F. Smets, August 2003.

25 I "Consumption, habit persistence, imperfect information and the lifetime budget constraint" by A. Willman, August 2003.

252 "Interpolation and backdating with a large information set" by E. Angelini, J. Henry and M. Marcellino, August 2003.

253 "Bond market inflation expectations and longer-term trends in broad monetary growth and inflation in industrial countries, 1880-200I" by W. G. Dewald, September 2003. 
254 "Forecasting real GDP: what role for narrow money?" by C. Brand, H.-E. Reimers and F. Seitz, September 2003.

255 "Is the demand for euro area M3 stable?" by A. Bruggeman, P. Donati and A. Warne, September 2003.

256 "Information acquisition and decision making in committees: a survey" by K. Gerling, H. P. Grüner, A. Kiel and E. Schulte, September 2003.

257 “Macroeconomic modelling of monetary policy” by M. Klaeffling, September 2003.

258 "Interest rate reaction functions and the Taylor rule in the euro area" by P. GerlachKristen, September 2003.

259 "Implicit tax co-ordination under repeated policy interactions" by M. Catenaro and J.-P. Vidal, September 2003.

260 "Aggregation-theoretic monetary aggregation over the euro area, when countries are heterogeneous” by W. A. Barnett, September 2003.

261 "Why has broad money demand been more stable in the euro area than in other economies? A literature review” by A. Calza and J. Sousa, September 2003.

262 "Indeterminacy of rational expectations equilibria in sequential financial markets" by P. Donati, September 2003.

263 "Measuring contagion with a Bayesian, time-varying coefficient model" by M. Ciccarelli and A. Rebucci, September 2003.

264 "A monthly monetary model with banking intermediation for the euro area" by A. Bruggeman and M. Donnay, September 2003.

265 "New Keynesian Phillips Curves: a reassessment using euro area data" by P. McAdam and A. Willman, September 2003.

266 "Finance and growth in the EU: new evidence from the liberalisation and harmonisation of the banking industry" by D. Romero de Ávila, September 2003.

267 "Comparing economic dynamics in the EU and CEE accession countries" by R. Süppel, September 2003.

268 "The output composition puzzle: a difference in the monetary transmission mechanism in the euro area and the US" by I. Angeloni, A. K. Kashyap, B. Mojon and D. Terlizzese, September 2003.

269 "Zero lower bound: is it a problem with the euro area?" by G. Coenen, September 2003.

270 "Downward nominal wage rigidity and the long-run Phillips curve: simulation-based evidence for the euro area" by G. Coenen, September 2003.

27I “Indeterminacy and search theory” by N. Giammarioli, September 2003. 
272 "Inflation targets and the liquidity trap" by M. Klaeffling and V. López Pérez, September 2003.

273 "Definition of price stability, range and point inflation targets: the anchoring of long-term inflation expectations" by E. Castelnuovo, S. Nicoletti-Altimari and D. RodriguezPalenzuela, September 2003.

274 "Interpreting implied risk neutral densities: the role of risk premia" by P. Hördahl and D. Vestin, September 2003.

275 "Identifying the monetary transmission mechanism using structural breaks" by A. Beyer and R. Farmer, September 2003.

276 "Short-term estimates of euro area real GDP by means of monthly data" by G. Rünstler and F. Sédillot, September 2003.

277 "On the indeterminacy of determinacy and indeterminacy" by A. Beyer and R. Farmer, September 2003.

278 "Relevant economic issues concerning the optimal rate of inflation" by D. R. Palenzuela, G. Camba-Méndez and J. Á. García, September 2003.

279 "Designing targeting rules for international monetary policy cooperation" by G. Benigno and P. Benigno, October 2003.

280 “Inflation, factor substitution and growth" by R. Klump, October 2003.

28I "Identifying fiscal shocks and policy regimes in OECD countries" by G. de Arcangelis and S. Lamartina, October 2003.

282 "Optimal dynamic risk sharing when enforcement is a decision variable" by T. V. Koeppl, October 2003.

283 "US, Japan and the euro area: comparing business-cycle features" by P. McAdam, November 2003.

284 "The credibility of the monetary policy 'free lunch"' by J. Yetman, November 2003.

285 "Government deficits, wealth effects and the price level in an optimizing model" by B. Annicchiarico, November 2003.

286 "Country and sector-specific spillover effects in the euro area, the United States and Japan" by B. Kaltenhaeuser, November 2003.

287 “Consumer inflation expectations in Poland” by T. Łyziak, November 2003.

288 “Implementing optimal control cointegrated I(I) structural VAR models" by F. V. Monti, November 2003.

289 "Monetary and fiscal interactions in open economies" by G. Lombardo and A. Sutherland, November 2003. 
290 "Inflation persistence and robust monetary policy design" by G. Coenen, November 2003.

291 "Measuring the time-inconsitency of US monetary policy” by P. Surico, November 2003.

292 "Bank mergers, competition and liquidity" by E. Carletti, P. Hartmann and G. Spagnolo, November 2003.

293 "Committees and special interests" by M. Felgenhauer and H. P. Grüner, November 2003.

294 "Does the yield spread predict recessions in the euro area?" by F. Moneta, December 2003.

295 “Optimal allotment policy in the eurosystem's main refinancing operations?" by C. Ewerhart, N. Cassola, S. Ejerskov and N. Valla, December 2003.

296 "Monetary policy analysis in a small open economy using bayesian cointegrated structural VARs?" by M. Villani and A. Warne, December 2003.

297 “Measurement of contagion in banks' equity prices” by R. Gropp and G. Moerman, December 2003.

298 "The lender of last resort: a 2 I st century approach" by X. Freixas, B. M. Parigi and J.-C. Rochet, December 2003.

299 "Import prices and pricing-to-market effects in the euro area" by T. Warmedinger, January 2004.

300 "Developing statistical indicators of the integration of the euro area banking system" by M. Manna, January 2004.

301 "Inflation and relative price asymmetry” by A. Rátfai, January 2004.

302 “Deposit insurance, moral hazard and market monitoring” by R. Gropp and J. Vesala, February 2004.

303 "Fiscal policy events and interest rate swap spreads: evidence from the EU" by A. Afonso and R. Strauch, February 2004.

304 "Equilibrium unemployment, job flows and inflation dynamics" by A. Trigari, February 2004.

305 "A structural common factor approach to core inflation estimation and forecasting" by C. Morana, February 2004.

306 "A markup model of inflation for the euro area” by C. Bowdler and E. S. Jansen, February 2004.

307 "Budgetary forecasts in Europe - the track record of stability and convergence programmes" by R. Strauch, M. Hallerberg and J. von Hagen, February 2004.

308 "International risk-sharing and the transmission of productivity shocks" by G. Corsetti, L. Dedola and S. Leduc, February 2004.

309 "Monetary policy shocks in the euro area and global liquidity spillovers" by J. Sousa and A. Zaghini, February 2004.

310 "International equity flows and returns: A quantitative equilibrium approach" by R. Albuquerque, G. H. Bauer and M. Schneider, February 2004.

311 "Current account dynamics in OECD and EU acceding countries - an intertemporal approach" by M. Bussière, M. Fratzscher and G. Müller, February 2004. 
312 "Similarities and convergence in G-7 cycles" by F. Canova, M. Ciccarelli and E. Ortega, February 2004.

313 "The high-yield segment of the corporate bond market: a diffusion modelling approach for the United States, the United Kingdom and the euro area" by G. de Bondt and D. Marqués, February 2004.

3।4 "Exchange rate risks and asset prices in a small open economy" by A. Derviz, March 2004.

315 "Option-implied asymmetries in bond market expectations around monetary policy actions of the ECB" by S. Vähämaa, March 2004.

316 “Cooperation in international banking supervision” by C. Holthausen and T. Rønde, March 2004.

317 “Fiscal policy and inflation volatility" by P. C. Rother, March 2004.

318 "Gross job flows and institutions in Europe” by R. Gómez-Salvador, J. Messina and G. Vallanti, March 2004.

319 "Risk sharing through financial markets with endogenous enforcement of trades” by T. V. Köppl, March 2004.

320 "Institutions and service employment: a panel study for OECD countries" by J. Messina, March 2004.

321 "Frequency domain principal components estimation of fractionally cointegrated processes" by C. Morana, March 2004.

322 "Modelling inflation in the euro area” by E. S. Jansen, March 2004.

323 "On the indeterminacy of New-Keynesian economics" by A. Beyer and R. E. A. Farmer, March 2004.

324 “Fundamentals and joint currency crises” by P. Hartmann, S. Straetmans and C. G. de Vries, March 2004.

325 "What are the spill-overs from fiscal shocks in Europe? An empirical analysis" by M. Giuliodori and R. Beetsma, March 2004.

326 “The great depression and the Friedman-Schwartz hypothesis" by L. Christiano, R. Motto and M. Rostagno, March 2004.

327 "Diversification in euro area stock markets: country versus industry” by G. A. Moerman, April 2004.

328 "Non-fundamental exchange rate volatility and welfare” by R. Straub and I. Tchakarov, April 2004.

329 "On the determinants of euro area FDI to the United States: the knowledge-capital-Tobin's Q framework, by R. A. De Santis, R. Anderton and A. Hijzen, April 2004.

330 "The demand for euro area currencies: past, present and future” by B. Fischer, P. Köhler and F. Seitz, April 2004.

331 "How frequently do prices change? evidence based on the micro data underlying the Belgian CPI" by L. Aucremanne and E. Dhyne, April 2004.

332 "Stylised features of price setting behaviour in Portugal: 1992-200I" by M. Dias, D. Dias and P. D. Neves, April 2004. 
333 "The pricing behaviour of Italian firms: New survey evidence on price stickiness" by S. Fabiani, A. Gattulli and R. Sabbatini, April 2004.

334 "Is inflation persistence intrinsic in industrial economies?" by A. T. Levin and J. M. Piger, April 2004.

335 “Has eura-area inflation persistence changed over time?" by G. O’Reilly and K. Whelan, April 2004.

336 "The great inflation of the 1970s" by F. Collard and H. Dellas, April 2004.

337 "The decline of activist stabilization policy: Natural rate misperceptions, learning and expectations" by A. Orphanides and J. C. Williams, April 2004.

338 "The optimal degree of discretion in monetary policy" by S. Athey, A. Atkeson and P. J. Kehoe, April 2004.

339 “Understanding the effects of government spending on consumption” by J. Galí, J. D. López-Salido and J. Vallés, April 2004.

340 "Indeterminacy with inflation-forecast-based rules in a two-bloc model” by N. Batini, P.Levine and J. Pearlman, April 2004.

34I "Benefits and spillovers of greater competition in Europe: A macroeconomic assessment" by T. Bayoumi, D. Laxton and P. Pesenti, April 2004.

342 "Equal size, equal role? Interest rate interdependence between the euro area and the United States" by M. Ehrmann and M. Fratzscher, April 2004.

343 "Monetary discretion, pricing complementarity and dynamic multiple equilibria” by R. G. King and A. L. Wolman, April 2004.

344 "Ramsey monetary policy and international relative prices" by E. Faia and T. Monacelli, April 2004.

345 "Optimal monetary and fiscal policy: A linear-quadratic approach" by P. Benigno and M. Woodford, April 2004.

346 "Perpetual youth and endogenous labour supply: a problem and a possible solution" by G. Ascari and N. Rankin, April 2004.

347 'Firms' investment decisions in response to demand and price uncertainty" by C. Fuss and P. Vermeulen, April 2004.

348 “Financial openness and growth: Short-run gain, long-run pain?” by M. Fratzscher and M. Bussiere, April 2004.

349 "Estimating the rank of the spectral density matrix" by G. Camba-Mendez and G. Kapetanios, April 2004.

350 "Exchange-rate policy and the zero bound on nominal interest rates" by G. Camba-Mendez and G. Kapetanios, April 2004. 
